\title{
Protection of intellectual property of an architect
}

\author{
Nicolay Zhilskiy ${ }^{1}$, Emma Shariapova ${ }^{1}$ and Marina Matveeva ${ }^{1, *}$ \\ ${ }^{1}$ Saint Petersburg State University of Architecture and Civil Engineering, 190005, Vtoraja \\ Krasnoarmejskaja ul. 4, St. Petersburg, 190005, Russia
}

\begin{abstract}
In the paper, the authors raise the issue of protecting the copyright of an architect. One of the ways to protect it is the trial. The RF Constitution guarantees judicial protection of rights and freedoms. Recently, in the Russian Federation, the number of appeals to the court for copyright protection has increased, indicating a large number of infringements of intellectual property rights of architects. The study of the authors showed that often the cause of litigation is the discrepancy of the values of the objects of copyright of the architect. To interpret such concepts as "architectural solution", "architectural design", "architect's concept", "architect's idea" and others, the court is forced to involve specialists whose opinions in the court decision become the source of law, which contradicts the theory of state and law. The authors believe that the legislative consolidation of clear, certain essential features of the conceptual and categorical framework used in architectural activity is the improvement of the protection mechanism for the works of architects that are the result of their creative activity.
\end{abstract}

\section{Introduction}

Based on etymology, the concept of "architect" dates back to ancient Greece. Architect is the oldest profession. The appearance of this profession is explained by the fact that housing for a person has always been and will be a symbol of security and safety. No wonder the right to housing is enshrined constitutionally in many countries.

According to Dal, architecture [1] is the art of disposing, building and decorating buildings; construction art, architectonic.

The following definition is given by Ozhegov [2]: architecture - art of building, architectonic. In his explanatory dictionary of the Russian language, Ushakov [3] gives 4 meanings of art, which are based on creative artistic activity. Dmitry Nikolaevich calls architecture as one of the types of art.

Thus, the importance of the profession of an architect can be traced on the basis of the emphasis that was given by the master of literature at different times.

Architecture has always belonged to the types of art. Therefore, the result of the work of the architect is subject to copyright. Disputes about what is the subject of copyright have long been resolved both at the legislative level and among theorists. So, for example, K.D.

*Corresponding author: spetrova@lan.spbgasu.ru 
Shestakova [4] and N.V. Slesaryuk [5] recognize the building as the object of copyright. But D. K. Hautov [6], A. Dumanskaya, O. P. Popova [7], and R. Merzlikina [8] believe that the product of architecture and urban planning should have an objective form of expression; therefore, subject to copyright is a project. N.M. Golovanov [9], on the other hand, considers it necessary to distinguish between an architectural object as a work of art and an object built according to this project.

Regardless of what is recognized as a copyright object, copyright itself is subject to protection. The Constitution of the Russian Federation of 1993 proclaims: "In the Russian Federation, private, state, municipal and other forms of ownership are equally recognized and protected". [10]

Intellectual property of the architect as a form of ownership is also subject to protection, and this is reflected in other legal acts. In Article 1225 of the Civil Code of the Russian Federation, the legislator calls works of science, literature, and art one of the protected results of intellectual activity and means of individualization. [11]

\section{Materials and Methods}

Table 1 clearly shows that the subject of the dispute, as a rule, is an objective material - an architectural project or project documentation. So, in the case of the plaintiff LLC "Zapsibelectroengineering", the court makes a decision, referring to part 2 of Article 48 of the Town Planning Code of the Russian Federation, in which it substantiates the object of copyright - an architectural project that “... the object of copyright is not construction documentation in general, but only an architectural project (part of the project documentation) in which the architectural solution is expressed" [17]

Table 1. Comparative analysis of some court decisions on the protection of the violated exclusive right of the architect over the past 2 years.

\begin{tabular}{|c|c|c|c|c|c|}
\hline & $\begin{array}{c}\text { Leninsky } \\
\text { District } \\
\text { Court of St. } \\
\text { Petersburg } \\
{[12]}\end{array}$ & $\begin{array}{l}\text { Arbitration Court of } \\
\text { Moscow [13] }\end{array}$ & $\begin{array}{c}\text { Ninth } \\
\text { Arbitration } \\
\text { Court of } \\
\text { Appeal [14] }\end{array}$ & $\begin{array}{l}\text { Arbitration } \\
\text { Court of } \\
\text { the Ryazan } \\
\text { Region } \\
\text { [15] }\end{array}$ & $\begin{array}{c}\text { Central } \\
\text { District } \\
\text { Court of } \\
\text { Omsk [16] }\end{array}$ \\
\hline Case of & 17.08 .2017 & 21.02 .2018 & 29.01 .2018 & 17.04 .2018 & 18.01 .2018 \\
\hline $\begin{array}{l}\text { Plaintiff, } \\
\text { Responde } \\
\text { nt }\end{array}$ & $\begin{array}{l}\text { Lagutin } \\
\text { D.A., } \\
\text { Nikolayenk } \\
\text { ov A.S. }\end{array}$ & $\begin{array}{c}\text { LLC } \\
\text { "Zapsibelectroengineeri } \\
\text { ng", } \\
\text { PJSC "FGC UES" }\end{array}$ & $\begin{array}{c}\text { LLC } \\
\text { "Architectur } \\
\text { al workshop } \\
\text { "ABV } \\
\text { Group“, } \\
\text { Joint Stock } \\
\text { Company } \\
\text { "SK } \\
\text { DONSTRO } \\
\text { Y" }\end{array}$ & $\begin{array}{c}\text { Limited } \\
\text { Liability } \\
\text { Company } \\
\text { Architectur } \\
\text { al Bureau } \\
\text { "A- } \\
\text { Studio", } \\
\text { Limited } \\
\text { Liability } \\
\text { Company } \\
\text { "Coliseum }\end{array}$ & $\begin{array}{c}\text { Architect } \\
\text { Begun } \\
\text { A.V., } \\
\text { citizen } \\
\text { Kuropatkin } \\
\text { a E.P. }\end{array}$ \\
\hline $\begin{array}{l}\text { Subject of } \\
\text { action }\end{array}$ & $\begin{array}{l}\text { Protection } \\
\text { of the } \\
\text { violated } \\
\text { exclusive } \\
\text { right of the } \\
\text { architect }\end{array}$ & $\begin{array}{l}\text { Protection of the } \\
\text { violated exclusive right } \\
\text { of the architect }\end{array}$ & $\begin{array}{l}\text { Protection } \\
\text { of the } \\
\text { violated } \\
\text { exclusive } \\
\text { right of the } \\
\text { architect }\end{array}$ & $\begin{array}{l}\text { Protection } \\
\text { of the } \\
\text { violated } \\
\text { exclusive } \\
\text { right of the } \\
\text { architect }\end{array}$ & $\begin{array}{l}\text { Protection } \\
\text { of the } \\
\text { violated } \\
\text { exclusive } \\
\text { right of the } \\
\text { architect }\end{array}$ \\
\hline $\begin{array}{l}\text { Subject of } \\
\text { the } \\
\text { dispute }\end{array}$ & $\begin{array}{l}\text { Architectur } \\
\text { al solution }\end{array}$ & Architectural project & $\begin{array}{l}\text { Architectura } \\
1 \text { solution }\end{array}$ & $\begin{array}{l}\text { Architectur } \\
\text { al project }\end{array}$ & $\begin{array}{c}\text { Architectur } \\
\text { al project }\end{array}$ \\
\hline
\end{tabular}


Data from the table show:

1) Mass character of assertion of the rights in modern times, in particular, the copyright of architects.

2) An increase in the number of appeals to the courts for copyright protection, which indicates an increase in violations in the field of intellectual property of the architect.

3) The presence of cases where the subject of the dispute arises due to the absence or ambiguity of the conceptual and categorical framework.

Collisions arise because of the vagueness of the subject of the dispute. In the above solution, the concepts of "project documentation", "architectural project", "architectural solution" are encountered, which smoothly replace each other. The authors of the paper believe that there is a significant difference between these concepts, although it can be considered doctrinal. Some concepts are reflected in the legislation, for example, such as "architectural solution", "architectural design". Some concepts do not have a statutory semantic meaning, therefore the concepts of "architectural solution", "architectural design", "architect's concept", "architect's idea", and others are often mixed. Components of project and working documentation are forced by many lawyers, including judges, to be reduced to an architectural project or architectural solution, which is only enshrined in the norm of Russian law.

\section{Results}

The basis of the legal regulation of the protection of copyright of architects of the Russian Federation is both international and national legislation. One of the principles of the Berne Convention on the Protection of the Rights of Authors refers to the provision of protection in all state parties to the Convention, regardless of whether there is national legislation on the protection of copyright. [18]

The Berne Convention for the Protection of Literary and Artistic Works extends protection to the following works of art, science, and literature: lectures, books, brochures, drawings, sculptures, paintings, architecture, photography, graphics, choreography, music, cinematographic works, etc. The term for which it is provided is the lifetime of the author of the work and 50 years after his death. In the Russian Federation, a particular part of legislation protects the intellectual property of the architect. In accordance with Article 1259 of the Civil Code of the Russian Federation, objects of copyright are works of science, literature, and art, regardless of the merits and purpose of the work, as well as the way it is expressed, including works of architecture, town planning, and landscape art, including in the form of: projects, drawings, images, and layouts. The Civil Code extends to the architect's copyright all the following rights: exclusive right to a work, rights of authorship, author's rights to the name, to the inviolability of the work and to its publication. The authors believe that issues on the protection of intellectual property often arise due to weak argumentation, which, by its nature, has an indefinite conceptual framework.

\section{Discussion}

Previously, the architect did not have to protect his right to the result of architectural activity, since the architect was the subject who received the order for the project and embodied his vision (design) in architectural solutions. Then, coordinating with the customer, he embodied the project into reality, starting with engineering surveys and ending with commissioning. In other words, he acted as the architect, and the developer, and the technical director, and the head of construction and design control and supervision. 
In modern times, because of the division of labor, the architect only provided for the creation of project documentation on the basis of a civil law contract. There are a lot of questions in relation to the implemented project as a result of intellectual property. Today, when the freedom of the architect is limited in terms of the implementation of the design, the activity of the architect is more and more subject to the construction industry, and the intellectual property of the architect takes place only at the stage of transformation of the architectural solution into a project. The restriction of creativity was explained by the Soviet time with the practice of embellishment in construction, which explains such legal acts as the Resolution of the Central Committee of the CPSU on November 4, 1955 No. 1871 "On the elimination of excesses in design and construction". [19]

The activity of the architect is a creative activity, namely, the activity of implementing the idea into the project. The process of implementation takes place in several stages:

1) Task setting (in the construction activity, it is called an architectural and planning assignment from the customer);

2) The emergence of an idea (design) of the project;

3) The embodiment of the idea in the architectural solution;

4) The implementation of architectural solution in the project.

Starting from stage 3 , the idea of the project acquires integrity on a tangible form, and from that moment, the copyright object arises. Article 16 of the Federal Law No. 169 "On Architectural Activity in the Russian Federation" states: "The objects of copyright to works of architecture are the architectural project, construction documentation developed on its basis, as well as the architectural object". [20]

Meanwhile, the Civil Code of the Russian Federation establishes: "Copyright does not apply to ideas, concepts, principles, methods, processes, systems, ways, solutions of technical, organizational or other tasks, discoveries, facts, programming languages, geological information about the subsurface". The question about the conceptual and categorical framework accompanying architectural activity is very acute. Considering that the activity of the architect is creative and intellectual, it seems important to distinguish between the concepts of architectural design and architectural solution. In Federal Law No. 169 , the concept of "architectural design" is presented as an equivalent concept of "architectural solution": "The architectural solution - the author's design of an architectural object - its external and internal appearance, spatial, planning, and functional organization, which was recorded in the architectural part of the documentation for construction and implemented in the constructed architectural object". However, the embodiment of the design as a stage of architectural creativity is not subject to copyright. This stage is important because it underlies the architectural solution. But in the architectural solution, the same idea can take on different forms. The conceptual meaning of such words as "architect's concept" and "architect's idea" is not defined. However, they are often used in solving issues about the architectural solution and architectural design. If we turn to the dictionary of Ushakov D.N., then the concept is a design, a theoretical construction, and an idea is a thought, a concept about an object, an image comprehended by the mind. [3] As we can see, these are abstract concepts that do not have well-defined essential features. Sometimes this is the cause of disputes between architects and other subjects in a dispute over the protection of the intellectual property of the architect.

In the Leninsky District Court of St. Petersburg, a dispute was considered between two architects over the violation of the architect's exclusive right to an architectural solution (case of August 17, 2017). The subject of the claim of Lagutin D.A. was a violation of his copyright. During the consideration of the case, it turned out that the architects Lagutin and Nikolaenkov presented the same projects, which coincided in 4 points: the use of a metal strip along the central axis of the street along its entire length, the color solution of the paving (the central part of gray stone and the framing of red color stone), decorative pattern 
in the form of a circle on the section of the street between the houses № $<\ldots>$ on B. Morskaya Street and № < ... $>$ on Nevsky Prospect, the number of lamps - five on each side of the street.

However, in the conclusion of the expert, it is recognized that the materials submitted by the parties are not architectural projects containing an architectural solution, but are concepts that are not related to copyright objects. Based on the expertise, the court decides to deny Lagutin's claims, especially since the latter refuses the words "design". [12]

Based on the foregoing, it can be concluded that the professional architects themselves are often confused with the concepts of "design", "concept", and "solution". This is reflected in the NOPRIZ Resolution on the results of the Round Table "Actual issues of copyright in architectural design. Legislation and practice of application" dated August 10, 2016 in Moscow. In paragraph 2 of the Resolution, attention is focused on the fact that in world practice, the architectural design itself has long been subject to copyright even at an unimplemented stage. Also, in paragraph 4, the participants agreed that it is necessary in the regulatory framework to bring about clear legal certainty between participants in the construction process in the circulation of intellectual property. [21]

\section{Conclusions}

The authors emphasized the features of the architect's copyright, which are associated with the absence or ambiguity of the conceptual and categorical framework. The study showed that such concepts as "architectural solution", "architectural design", "concept", and "idea" are often both synonyms and interchangeable concepts, which leads to uncertainty of situations. So, in the case of August 17, 2017, where these concepts are encountered and, due to the absence of legally enshrined concepts, an expert is invited, whose testimony forms the basis of the judicial decision, which means the opinion of the expert, even authoritative one, is also a source of law for a judicial decision. [12]

Table 2. Indicators of legislative consolidation of concepts in the law.

\begin{tabular}{|c|c|c|c|c|}
\hline & Architectural solution & Architectural design & $\begin{array}{c}\text { Architect's } \\
\text { concept }\end{array}$ & $\begin{array}{c}\text { Architect's } \\
\text { idea }\end{array}$ \\
\hline $\begin{array}{c}\text { Legislative } \\
\text { consolidati } \\
\text { on }\end{array}$ & $\begin{array}{c}\text { Federal Law №169 } \\
\text { "On the architectural } \\
\text { activity in the Russian } \\
\text { Federation" }\end{array}$ & $\begin{array}{c}\text { Refers to as a species } \\
\text { to the generic concept } \\
\text { of “architectural } \\
\text { solution” }\end{array}$ & is missing & is missing \\
\hline
\end{tabular}

This table is characterized by the fact that it shows how relative the conceptual and categorical framework used, in particular, in the protection of the intellectual property of the architect. The authors support the need for a legislative rethinking of concepts related to the creative activity of the architect, to the realization of his copyright to the work, in order to avoid collisions in protecting the intellectual property of the architect.

The 1993 Constitution of the Russian Federation enshrined the right to protection of rights and freedoms by all legal means. Every year, the number of appeals of architects and architectural bureaus for the protection of intellectual property to the court of various instances grows, which reflects the development of real democracy in the Russian Federation. "Architecture is not a profession for the faint-hearted, the weak-willed, or shortlived", said critic Martin Filler [22].

\section{References}

1. V.I. Dal, Explanatory dictionary of the Russian language: illustrated edition (Eksmo, 
Moscow, 2015)

2. S.I. Ozhegov, Explanatory dictionary of the Russian language: About 100000 words, terms, and phraseological expressions (ONIKS-LIT, Mir i Obrazovznie, Moscow, 2012)

3. D.N. Ushakov, Explanatory dictionary of the modern Russian language: About 100,000 words (Adelant, Moscow, 2013)

4. K.D. Shestakova, Bulletin of St. Petersburg University 4, 17-28 (2010)

5. N.V. Slesaryuk, Law and Economics 9, 20-31 (2012)

6. D.K. Hautov, Bulletin of the North Ossetian State University named after K.L. Khetagurov 2, 35-49 (2011)

7. A. Dumanskaya, O. P. Popova Scientific notes of PNU 4-4, 29-45 (2013)

8. R. Merzlikina, Copyright and related rights 1, 10-17 (2015)

9. N.M. Golovanov, Collection of articles of the International Scientific and Practical Conference 3, 158-163 (2017) 